\title{
糖アルコールの特性と利用 \\ Characteristics and Applications of Sugaralcohols
}

\author{
布 施 雅 昭 \\ Fuse Masaaki \\ （東和化成工業株式会社調査室） \\ Towa Chemical Industny Co. Ltd,
}

\section{1． 糖アルコールとは}

糖アルュールの中でも, ソルビトールは, 今世紀半ば から利用されるよらになった歴史的には比較的古い食品 素材で, 加工食品の物性改善には, 既に馴染み深い素材 である。しかし，ソルビトールといら個別の名称もさる ことながら, “糖アルコール”に至っては, “アルコール” といら言葉のために, 特に消費者には奇異で理解しにく い名称のようである。

糖アルコールは, 糖の還元基（アルデヒド基, カルボ
ニル基）が水素付加（添加）によりアルコール基となる ことからこのよらに呼ばれており, これは分類上の名称 である。

自然界に执ける糖の種類には, 単糖類, オリゴ糖, 多 糖類があるが, これらに対応して, 単糖アルコール, オ リゴ糖アルコール，多糖アルコールがある（表 1)。通 常, 糖アルコールの名称は, 糖の語尾の-ose (例 : Xylose)を-itol(例 : Xylitol)むたは-it(例 : Xylit)に変えて 名つけられる。

表 1 糖・糖アルコール対応表

\begin{tabular}{|c|c|c|c|c|}
\hline & 区分 & 類 & 糖アルコール類 & 摘 \\
\hline 類 & $\begin{array}{l}\text { 三炭糖 } \\
\text { 四炭糖 } \\
\text { 五炭糖 }\end{array}$ & $\begin{array}{l}\text { エリスロース } \\
\text { キシロース } \\
\text { リボース } \\
\text { アラビノース } \\
\text { ガラクトース } \\
\text { グルュース } \\
\text { ソルボース } \\
\text { フラクトース } \\
\text { マンノース }\end{array}$ & $\begin{array}{l}\text { グリセロール } \\
\text { エリスリトール } \\
\text { キシリトール } \\
\text { リビトール } \\
\text { アラビトール } \\
\text { ガラクチトール } \\
\text { ソルビトール } \\
\text { ソルビトール } \\
\text { イジトール } \\
\text { ソルビトール } \\
\text { マンニトール } \\
\text { マンニトール }\end{array}$ & $\begin{array}{l}\text { 脂肪成分, 発酵食品 } \\
\text { きのこ, 果実類, 発酵食品 } \\
\text { いちご, 野菜類 } \\
\text { きのこ類, 地衣類 } \\
\text { 紅藻類 } \\
\text { ‘゙ラ科植物, 夏みかん, ぶどらなど } \\
\text { きのこ類, 海草類 }\end{array}$ \\
\hline $\begin{array}{l}\text { オ } \\
\text { 1) } \\
\text { 工 } \\
\text { 糖 } \\
\text { 多 } \\
\text { 糖 } \\
\text { 数 }\end{array}$ & $\begin{array}{c}\text { 二糖類 } \\
\text { 三糖類 } \\
\text { 四糖類 } \\
\vdots \\
\text { その他 }\end{array}$ & $\begin{array}{l}\text { パラチノース } \\
\text { マルトース } \\
\text { ラクトース } \\
\text { マルトトリオース } \\
\text { イソマルトトリオース } \\
\text { マルトテトラオース } \\
\text { イソマルトテトラオース } \\
\vdots \\
\text { 糖化度別水あめ類 }\end{array}$ & $\begin{array}{c}\text { パラチニット } \\
\text { マルチトール } \\
\text { ラクチトール } \\
\text { マルトトリイトール } \\
\text { イソマルトトリイトール } \\
\text { マルトテトライトール } \\
\text { イソマルトテトライトール } \\
\quad \vdots \\
\text { 糖化度別還元水あめ類 }\end{array}$ & $\begin{array}{c}\text { 食品扱い } \\
\text { " } \\
\text { " } \\
\text { " } \\
\text { " } \\
\text { " } \\
\text { " }\end{array}$ \\
\hline
\end{tabular}

（注） 単糖類系の摘要闌には, 自然界における分布を示した

本稿は第17回研究集会の発題講演を纏めたものである. 
<smiles>O=CC1CCCCC1CCO</smiles>

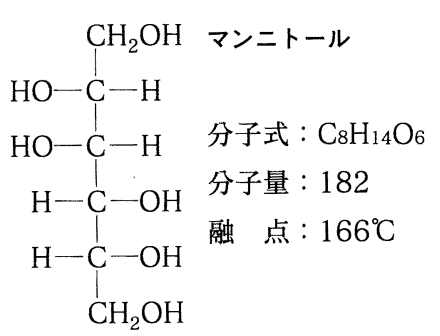

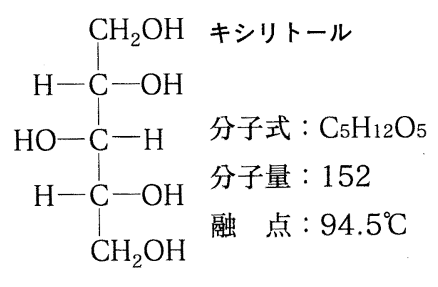<smiles>OCC(O)C(O)C(O)C(OC[C@H]1O[C@H](CO)[C@H](O)[C@@H](O)[C@@H]1O)C(O)CO</smiles>

$$
\text { マルチトール }
$$$$
\text { 分子式 : } \mathrm{C}_{12} \mathrm{H}_{24} \mathrm{O}_{11}
$$$$
\text { 分子量 : } 344
$$

融点 : $147-150^{\circ} \mathrm{C}$

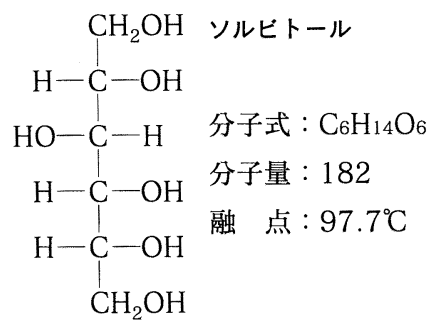<smiles>OC[C@H](O)[C@@H](O)[C@H](O)[C@H](OCC(O)[C@H](O)CO)[C@@H](O)[C@H](O)[C@H](O)CO</smiles>

ラクチトール

分子式 : $\mathrm{C}_{12} \mathrm{H}_{24} \mathrm{O}_{11} \cdot \mathrm{H}_{2} \mathrm{O}$ 分子量：362

融 点: 一

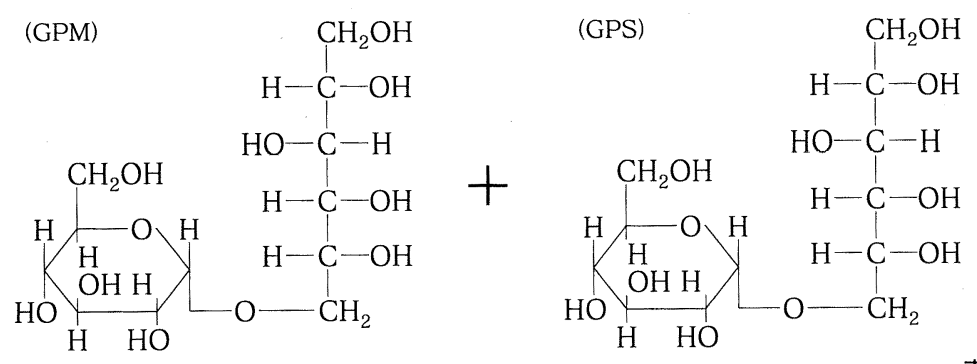

パラチニット

分子式 : $\mathrm{C}_{12} \mathrm{H}_{24} \mathrm{O}_{11} \cdot 2 \mathrm{H}_{2} \mathrm{O}, \mathrm{C}_{12} \mathrm{H}_{24} \mathrm{O}_{11}$

分子量 : 380,344

融 点: $145-150^{\circ} \mathrm{C}$

図 1 糖アルコールの構造式

食品素材として利用されている糖アルコールの構造式 を図 1 亿示す。これらの中で, 単糖アルコールは, 自然 界にそのままの形で存在することが知られている。 エリ スリトールは, ワイン, 奨油及び味噌に多く含まれる1) (表 2). キシリトールは, プラムやカリフラワーなど の果実や野菜に多く含まれる2（表 3 ）。、ンニトール は海藻類にかなり多く含まれ, ラウスコンブでは乾物重 量の $40 \%$ がマンニトールである3（表 4 ）.
表 2 自然界におけるエリスリトールの存在

\begin{tabular}{|c|c|c|}
\hline & 種＼cjkstart類 & 含 量 \\
\hline 生物中 & $\begin{array}{lll}\text { 地 } & \text { 衣 } & \text { 類 } \\
\text { アサの } & \text { 葉 } \\
\text { きの } & \text { こ }\end{array}$ & $\begin{array}{l}0.3 \sim 5 \quad(\%) \\
0.1 \\
2 \sim 4\end{array}$ \\
\hline 食品中 & 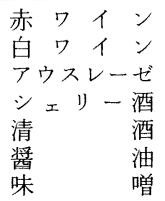 & $\begin{array}{l}170(\mathrm{mg} / \mathrm{l}) \\
280 \\
300 \\
160 \sim 270 \\
150 \sim 180 \\
910 \\
1,310\end{array}$ \\
\hline
\end{tabular}

\section{2. 糖アルコールの製造方法}

糖アルコールの製造方法としては, 図 2 亿示すように, ニッケル触媒を用いた接触還元による水素添加法が一般 的である、エリスリトールは, 発酵法により製造される (図 3 ). 
日本食生活学会誌 Vol.10 No.3（1999）

表 3 果実, 野菜中のキシリトール含有量

\begin{tabular}{l|c}
\hline & 含有量 $(\mathrm{mg} / 100 \mathrm{~g}$ 乾物 $)$ \\
\hline バナナ & 21 \\
ラズベリー & 268 \\
ストロベリー & 362 \\
イェロープラム & 935 \\
にんじん & 86.5 \\
たまねぎ & 89 \\
レタス & 131 \\
カリフラワー & 300 \\
ほうれん草 & 107 \\
\hline
\end{tabular}

表 4 マンニトールを含む食品と含量等（乾物中）

\begin{tabular}{|c|c|c|}
\hline \multicolumn{2}{|r|}{ 名 } & \multirow{2}{*}{$\begin{array}{r}\text { 含量\% } \\
40\end{array}$} \\
\hline \multirow{7}{*}{$\begin{array}{l}\text { 藻 } \\
\text { 類 }\end{array}$} & ラウスコンブ & \\
\hline & マコンブ & $23 \sim 38$ \\
\hline & リシリコンブ & $22 \sim 31$ \\
\hline & ヒダカコンブ & $16 \sim 23$ \\
\hline & ナガコンブ & $2 \sim 16$ \\
\hline & ワ カ & $5 \sim 12$ \\
\hline & 七 $シ ゙ \quad \neq$ & $9 \sim 10$ \\
\hline \multirow{8}{*}{$\begin{array}{l}\neq \\
\text { f } \\
\text { ב } \\
\text { 類 } \\
\text { 等 }\end{array}$} & マ ッ タ ケ & $6.8 \sim 7.4$ \\
\hline & ヒラタ ケ & $4.9 \sim 7.5$ \\
\hline & エ, キダケ & $0.6 \sim 1.4$ \\
\hline & キクラゲ & 0.1 \\
\hline & シイタケ & \\
\hline & ホンシメジ & 0.1 \\
\hline & 八 ッ タ ケ & 3.0 \\
\hline & 七只 リ - & 4 \\
\hline
\end{tabular}

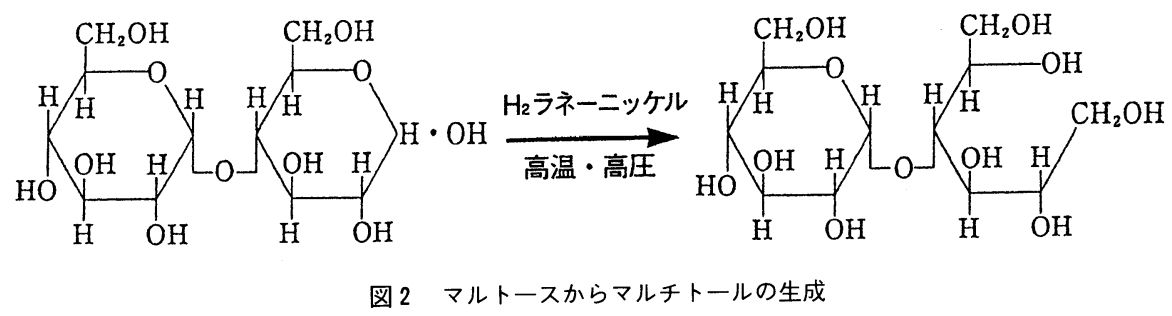

$\mathrm{CHO}$

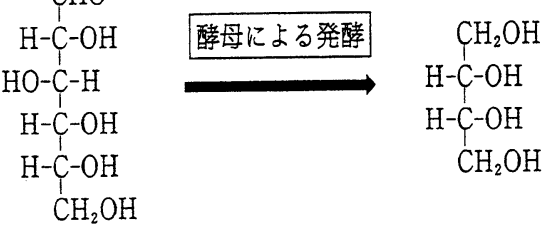

図 3 グリコースからエリスリトールの生成

表 5 糖アルコールの特性

\begin{tabular}{lccc}
\hline 糖アルコール & $\begin{array}{c}\text { 甘味度 } \\
(\text { スクロース }=100)\end{array}$ & $\begin{array}{c}\text { 溶解度 } \\
\left(25^{\circ} \mathrm{C}, \% \mathrm{w} / \mathrm{w}\right)\end{array}$ & $\begin{array}{c}\text { 溶解熱 } \\
(\mathrm{cal} / \mathrm{g})\end{array}$ \\
\hline ソルビトール & 60 & 75 & -26.5 \\
マンニトール & 50 & 18 & -28.9 \\
キシリトール & 100 & 63 & -36.6 \\
マルチトール & 80 & 62 & -5.5 \\
ラクチトール & 35 & 55 & -12.4 \\
パラチニット & 45 & 28 & -9.4 \\
エリスリトール & 75 & 36 & -42.9 \\
\hline
\end{tabular}




\section{3. 糖アルコールの特性}

糖アルコールに共通の特性として以下のようなものが 挙げられる。

\section{（1）甘味特性}

現在製品化されている糖アルコールはすべて甘味を有 する.キシリトールを除き，いずれもショ糖（スクロー ス）より甘味度は低い（表 5 ）。甘味の質は概ねショ糖 に似たまろやかさを示すが，低甘味のものはやや旨味に
欠ける. 種類によって高甘味度甘味料が示す味の悪さを 改善する効果を有する。 また，概ねクセがないので利用 食品の調味の特徵を生かすことができる.

\section{(2) 加工特性}

カルボニル基がないので,メイラード反応を起こさず, 非着色性である。耐熱性, 耐酸・耐アルカリ性に優れ, 概ね非発酵性である。 また, 吸湿性に優れ, 保湿効果の 高い特性を示すものと，逆に，低吸湿性を示すものがあ るので，用途に応じて選択することができる.

表 6 食品への糖アルコールの利用

\begin{tabular}{|c|c|c|}
\hline 利用目的 & 生か寸特徵 & 利用食品 \\
\hline $\begin{array}{l}\text { 甘味の低減 } \\
\quad \text { (糖度を下げずに甘味を低下) }\end{array}$ & 低甘味 & $\begin{array}{c}\text { 餡 クリーム類 } \\
\text { キャンディー ケーキ } \\
\text { 飲料 } \\
\end{array}$ \\
\hline $\begin{array}{l}\text { 増量 } \\
\text { (多量に添加しても甘くならない) }\end{array}$ & 低甘味 & $\begin{array}{c}\text { ソーセージ } \\
\text { 乾燥品 } \\
\text { 佃煮 }\end{array}$ \\
\hline 増量·賦形 & $\begin{array}{c}\text { 打錠性 } \\
\text { ユーティング性 }\end{array}$ & $\begin{array}{c}\text { 錠菓 } \\
\text { 糖衣ガム・キャンディー }\end{array}$ \\
\hline \multirow{7}{*}{ 保存性の向上 } & 難発酵性 & $\begin{array}{l}\text { ハム ソーセージ } \\
\text { 漬物 タレ類 }\end{array}$ \\
\hline & $\begin{array}{l}\text { 水分活性低下効果 } \\
\text { (浸透圧上昇効果) }\end{array}$ & $\begin{array}{l}\text { 乾燥品 ハム ソーセージ } \\
\text { 漬物 タレ類 佃煮 }\end{array}$ \\
\hline & $\begin{array}{c}\text { 離水防止効果 } \\
\text { (乳化安定) }\end{array}$ & $\begin{array}{l}\text { 冷凍食品 } \\
\text { クリーム類 }\end{array}$ \\
\hline & 保湿効果 & $\begin{array}{l}\text { 和菓子 冷凍食品 } \\
\text { 練りわさび・からし } \\
\text { めん類 クリーム類 }\end{array}$ \\
\hline & たんぱく質変性防止効果 & 冷凍すり身 \\
\hline & シャリ防止効果 & 餡 甘納豆 羊美 \\
\hline & 酸化防止効果 & $\begin{array}{l}\text { 果汁飲料 (Vc) } \\
ク_{ッ} \neq-(\text { 脂質) } \\
\end{array}$ \\
\hline 焼け・褐変防止 & $\begin{array}{c}\text { 耐熱性 } \\
\text { 酎アミノ酸性 }\end{array}$ & $\begin{array}{c}\text { タレ類 餭 } \\
\text { 焼き物 煮物 }\end{array}$ \\
\hline 浸透による食品への添加 & 高浸透性 & $\begin{aligned} & \text { 乾燥品 } \text { ドライフルーツ } \\
& \text { 八ム 者物 漬物 } \\
&\end{aligned}$ \\
\hline つや出し & 皮膜形成能 & 佃煮 羊美 餡 タレ類 \\
\hline 粘性調節 & 幅広い粘度特性 & $\begin{array}{l}\text { タレ類 クリーム類 } \\
\text { ソース ジャム 餡 }\end{array}$ \\
\hline 虫歯予防 & 非う蝕性 & $\begin{array}{c}\text { ガム キャンディー } \\
\text { チョコレート }\end{array}$ \\
\hline $\begin{array}{l}\text { 肥満予防 } \\
\text { ダイエット }\end{array}$ & $\begin{array}{c}\text { 難消化性 } \\
\text { (低カロリ-) }\end{array}$ & $\begin{array}{c}\text { カロリ一調節食品 } \\
\text { (ダイエット食品) } \\
\text { 卓上甘味料 }\end{array}$ \\
\hline 糖尿病予防 & $\begin{array}{c}\text { 血糖値・インスリンへの } \\
\text { 非関与性 }\end{array}$ & $\begin{array}{c}\text { 卓上甘味料 } \\
\text { 糖㽷病者用甘味料 }\end{array}$ \\
\hline
\end{tabular}




\section{(3) 生理学的特性}

非ら蝕性 : 糖アルコールは, 万蝕（虫歯の発生）の原 因菌である S. mutans などの口腔内細菌に利用されない ため, エナメル質の脱灰を引き起こす酸の産生, さらに 歯垢の原因となる不溶性グルカンの生成も見られない.

低ェネルギー：糖アルコールは，消化吸収が緩慢であ るために，撕取後の血糖值の上昇およびインスリン分泌 はほとんど見られず，低ェネルギー性を有している。

緩下作用 : 糖アルュールには, 難消化性糖質に共通し た緩下作用があり，一度に多量に摂取した時にはお腹が 緩くなることがある.1 回の摂取において下痢を誘発し ない最大掑取量は，体重 $\mathrm{kg}$ あたり $0.2 \mathrm{~g} \sim 0.6 \mathrm{~g}$ とされて (る4).

\section{4. 各種糖アルコールの特性と食品への利用}

糖アルコールは良質な甘味を有する糖質甘味料であ る. したがって, 食品に利用される場合は, ショ糖の代 替を目的としたものが多い. 表 6 は, 糖アルコール利用 食品をその利用目的ごとに分類したものである.さらに いくつかの糖アルコールについて, それぞれの特徵と利 用例を以下に示すが，実際の利用では，1種類だけでな く, 数種類の糖アルコールを組み合わせて使用する場合 が多くみられる.

エリスリトール：摂取しても大部分がそのまま体外に 排出されるため, エネルギーが $0 \mathrm{kcal} / \mathrm{g}$ である. 卓上 甘味料など低カロリ一の食品に利用される.

キシリトール：甘味度が高く, 味質の評価も高い、口 に含むと強い冷涼感があることから，錠菓やチューイン ガムなどに利用される.

マンニトール：吸湿性が低いので，チューインガムや あめ類の粘着防止のために使用される. 他の旨味成分と 組み合わせて調味料などにも利用される。

ソルビトール: 保湿性, 安定性に優れ, 安価であるこ とから, 畜肉・魚肉加工品, 佃惹, 珍味ほか, 様々な食 品で，品質保持を目的として利用される.

マルチトール：味質，加工適性ともショ糖に似ている ので, 汎用性が高く, シュガーレス食品の主要な素材で あり，数多くの食品に利用される.

ラクチトール：甘味は低いが，味質が良好で，チョコ レートなどによく利用される。

パラチニット：甘昧は低いが,ハードキャンディでは, 表面が透明でべとつかないなどの特性が利用される.

還元水飴：原料である水飴の種類によって様々な粘度
のものがあり，粘度調整や砂糖の結晶化防止のために， 和菓子などに利用される。

\section{5．糖アルコールと食品表示}

食品の表示は，消費者がそれを選択し食す上で重要な 情報であるので，その内容は，的確で公正なものでなけ ればならない，糖アルコールを使用した食品に関する表 示には次のようなものがある。

（1）シュガーレスの強調表示

平成 8 年より施行された栄養表示基準の強調表示に拉 いて，シュガーレス，ノンシュガーなどがすべて同意語 であると統一され，併せて糖類と糖アルコールの区分も 明確になった。シュガーとは糖類（単糖類および 2 糖類） を意味し，食品 $100 \mathrm{~g}$ あたりに含まれる糖類の量が $0.5 \mathrm{~g}$ 未満のときに，シュガーレス等の表示が可能で，その際 は糖類 $0 \mathrm{~g}$ も表示することとされている.

（2）特定保健用食品（特別用途食品）の許可表示

特定保健用食品は厚生省が定める表示許可制度であ り,このなかで糖アルコールを利用したチューインガム， チョコレートやキャンディが「虫歯になりにくい食品」 として許可を得ている.

（3）病者用低カロリ一食品（特別用途食品）の許可表示 これも厚生省の表示許可制度であり，糖アルコールを 利用した食品では，糖尿病者用卓上甘味料として市販さ れている。

(4) Toothfriendly 食品のマーク表示

日本トゥースフレンドリー協会は, 摂取してから30分 間までの歯垢下 $\mathrm{pH}$ を測定 $\mathrm{pH} 5.7$ よ下がらないこと が確認された場合は，5蝕誘発性が活とんどない食品で あるとして，「歯に信頼」マークの表示をしている。

\section{(5) 注意表示}

消費者の過剰摂取について注意を促すために，「食べ 過ぎるとお腹が緩くなることがあります」等の任意表示 がされている場合がある。

\section{参考文献}

1）社団法人菓子総合技術センター：農林水産省食品流通 局委託事業「飲食料品機能性素材有効利用技術シリーズ, No. 6エリスリトール」, 平成 3 年 3 月.

2）同上：同じく「食品新素材有効利用技術シリーズ, No 10 キシリトール」, 平成10年 3 月.

3）同上：同じく「飲食料品機能性素材有効利用技術シリ一 ズ, No. 24 マンニトール」平成 6 年 3 月

4）奥恒行：日本臨床栄盖学会誌，11(2)，13-19（1990）. 